\title{
THE INFLUENCE OF STORE ATMOSPHERE ON REVISIT INTENTION AT SHOPPING TOURISM
}

\author{
Dwi Febrianty Nabila Wardani ${ }^{*}$, Budi Setiawan ${ }^{2}$, Fitria Dina Riana ${ }^{2}$ \\ ${ }^{1}$ Post Graduate Program, Faculty of Agriculture, University of Brawijaya, Indonesian \\ ${ }^{2}$ Faculty of Agriculture, University of Brawijaya, Indonesian \\ *corresponding author: wrdnnabila@gmail.com
}

\begin{abstract}
The tourism sector in Indonesia is growing rapidly, so the level of competition is getting higher. Shopping tourism is as one of the industries that is able to attract tourists must innovate considering the products that are sold are the same and the storeping behavior of tourists is different. This study used SEM-PLS analysis and was conducted on 110 respondents who visited Shopping Tourism in Batu city. The results showed that a welldesigned store atmosphere can stimulate positive emotions of tourists, provide comfort when shopping so as to create a memorable experience, and make tourists intend to visit again in the future. This study, not only provides recommendations for creating the right store atmosphere for retailers, but also provides information on understanding the storeping behavior of tourists.
\end{abstract}

Keyword: Store Atmosphere, Tourist Shopping Behaviour, Shopping Tourism, SEM-PLS

http://dx.doi.org/10.21776/ub.agrise.2021.021.4.6

Received 4 May 2021

Accepted 25 August 2021

Available online 31 October 2021

\section{INTRODUCTION}

Batu city is one of favorite destination for domestic and foreign tourists in East Java. This is indicated by the increasing number of tourist visits in the years. In 2017 the number of visitors reached 4.188.910 tourists, the number of tourists in 2018 and 2019 respectively reached 5.644.168 and 6.047.460 tourists.

Shopping tourism in Batu City also supports the development of the tourism sector. Shopping tourism in Batu City internally arises because there is a growth pattern of other sectors whose existence supports tourism, namely the horticultural processed micro gastronomy industry sector in the form of local cuisine (Renstra Disbudpar Batu City, 2013). Externally, tourist interest in shopping tourism continues to grow, because according to tourists shopping, especially for local cuisine, has an important position in the tourism, namely as part of a holiday experience or memories (Mossberg, 2007).

The number of tourist arrivals in Batu City shopping tourism managed to reach 626,126 visitors in 2017, but the last three years shopping tourism has decreased visitors, in 2018 to 2020 respectively as many as $598,450,470,644$, and 15,801 tourists. Meanwhile, the number of tourist visits is one of the indicators used to measure the development of the tourism industry. This can be seen from fluctuations in the number of visits and fluctuations in growth (Ariani and Aryanti, 2018).
The storeping behavior of every tourist is different. Young tourists can not stay at a certain shopping place, tourists tend to visit several stores before making a purchase decision, tourists also do not have a special list for shopping, even shopping often becomes an unplanned trip.

According to a shopping tourism retailer in Batu City, the problem that often occurs in their stores is chaotic circulation that cause uneffectve space function. Meanwhile, tourist groups are the target market of shopping tourism, where some of the tourists often have limited time constraints for shopping because tourists have their next travel agenda.

The role of the store atmosphere is very important due to changes in one's motives when shopping, where shopping activities are not only functional activities, namely to buy the desired product, but also get rest, entertainment, relaxation with a comfortable atmosphere. When a customer enters a store, they not only rate the product and the price offered, but they also respond to the environment created by the retailer. Especially in the case of Shopping Tourism, they tend to sell the same products, so highlighting their shop's services and shopping environment is a strategy that can attract tourists to visit.

A pleasant store atmosphere can be seen from the attributes that can attract the human senses, like sight, hearing, smell, and touch. The process of 
creating a store atmosphere, such as designing through visual communication, lighting, colors, music and fragrances, is designed to produce special influences or emotions and perceptions in consumers (Pradana and Wardana, 2019).

Lick (2016) states that lighting and color have shown a positive impact on customers in retail settings. In addition to lighting and color, the physical attributes of a store can make positive emotion and influencing buying behavior (Hulten, 2012).

Auditory in creating a store atmosphere is mostly to overcome the noise in the store. Research by Mufeeth and Mubarak (2019) applying music as a variable shows a positive influence on customer behavior, resulting in high levels of pleasure, arousal, and satisfaction after purchase. In this study, the researcher adapted the music variable and added noise pollution.

Errajaa (2020) shows that there is a positive influence of the suitability of the fragrance provided by the store on attitudes, pleasure, and perceptions of the store atmosphere. Customers feel the impact of instore fragrances, allowing for positive or negative feedback because they feel the fragrance is inappropriate. Research conducted by Errajaa (2020) suggests that olfactory is associated with loyalty and other things, not just fixing on brand image for further research. Therefore in this study, olfactory correlates with customer experience and revisit intention. Therefore, this research was conducted so that shopping tourism in Batu City is able to attract tourists back through the creation of a store atmosphere so that the number of visits increases.

\section{RESEARCH METHOD}

This type of research is classified as explanatory research. Explanatory research is research that aims to analyze the causal relationship and influence between two or more variables, through hypothesis testing.

This research activity was carried out in three shopping tourisms in Batu city, namely Brawijaya Istana Oleh-Oleh, Deduwa Pusat Oleh-Oleh, and KenDEDES Pusat Oleh-Oleh. The determination of the location was carried out purposively, with the consideration that the three were shopping tourisms that were located in Batu city with a nearby location and sold variants of similar products from food, handicrafts, and thers.

Table 1. Characteristic store atmosphere

\begin{tabular}{clcccccc}
\hline Indicator & & $\begin{array}{c}\text { Srongly } \\
\text { agree }\end{array}$ & Agree & Neutral & Disagree & $\begin{array}{c}\text { Stongly } \\
\text { disagree }\end{array}$ & Average \\
\hline $\mathrm{X}_{1.1}$ & Frekuency & 32 & 69 & 8 & 1 & 0 & 4.2 \\
& Percentage & $29.09 \%$ & $62.71 \%$ & $7.27 \%$ & $0.9 \%$ & - & 4.26 \\
$\mathrm{X}_{1.2}$ & Frekuency & 38 & 65 & 5 & 2 & 0 & 4.03 \\
& Percentage & $34.54 \%$ & $59.09 \%$ & $4.54 \%$ & $1.81 \%$ & - & 0 \\
$\mathrm{X}_{1.3}$ & Frekuency & 25 & 66 & 17 & 2 & 0 & - \\
& Percentage & $22.72 \%$ & $60 \%$ & $15.45 \%$ & 1.81 & &
\end{tabular}

Determination of respondents using nonprobability sampling method, namely accidental sampling. The practical rules contained in the book Multivariate Statistical Methods by Solimun (2017) is used to determint the sample size, referring to the first rule, which is ten times the number of manifest variables. There are 11 manifest variables in this study, so the sample used is 110 respondents.

The data were collected based on a questionnaire containing consumer perceptions about the store atmosphere, emotional responses, customer experiences, and revisit intention. All questions regarding consumer perceptions use a 5-point Likert scale (1: Strongly disagree, 2: Disagree; 3: Neutral; 4: Agree, 5: Strongly Agree).

This research uses descriptive analysis and Structural Equation Modeling-Partial Least Square (SEM-PLS) with WarpPLS 6.0. Structural Equation Modeling is part of multivariate statistics and supports analysis between several dependent and independent variables directly (Hair et al., 2014).

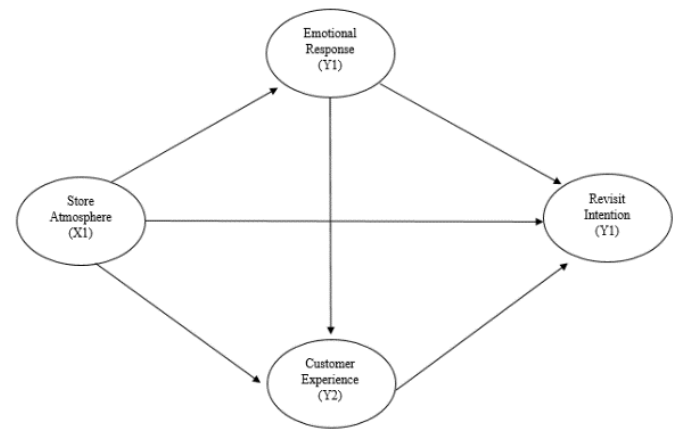

Figure 1. Inner Model

Source: Primary data, processed (2021)

\section{RESULT AND DISCUSSION \\ Characteristic Store Atmosphere}

Store atmosphere is a variable that describes shopping environment's design that is expected to stimulate the five senses, emotions and customer perceptions. This variable has four indicators to explain the formation of store atmosphere, namely visual (X1.1), olfactory (X1.2), auditory (X1.3), and tactile (X1.4). The following table presents a descriptive analysis of the store atmosphere variables from the distribution of questionnaires that have been filled out by respondents: 


\begin{tabular}{cccccccc}
$\mathrm{X}_{1.4}$ & Frekuency & 24 & 65 & 16 & 5 & 0 & 4.12 \\
& Percentage & $21.81 \%$ & $59.09 \%$ & $14.54 \%$ & $4.54 \%$ & - & 4.15 \\
\hline \multicolumn{10}{c}{ Average variable } \\
\hline \multicolumn{10}{c}{}
\end{tabular}

Source: Primary data, processed (2021)

The average visual indicator related to store design and aesthetics is 4.2 with $62.71 \%$ of the answers agreeing, meaning the store has succeeded in creating designs and aesthetics according to respondents. Visual indicators have six items, namely location, facilities, employees, design, layout, and product.

The results of the questionnaire show that respondents agree that the location of the store is strategic because the store is near the main road and has a clear signage.

The store has a large parking area equipped with public facilities such as toilets, waiting areas, and prayer rooms. Several respondents stated that before deciding to visit the store, they always consider the parking area and public facilities because apart from shopping they also rest, do worship and eat before continuing their journey.

All employees wear uniforms and pay attention to the neatness of their appearance. Respondents also revealed that when shopping, employees were very helpful and friendly in explaining questions so that store employee service was considered good.

The design chosen by the retailer is also an attraction for tourists. Brawijaya and KenDEDES dominate their store with white paint, while DeDuwa chooses more varied colors such as bright red, green, yellow, and purple. Respondents aged 20-30 years said they chose a store with bright colors like DeDuwa because the store has many places to take pictures.

The store has an orderly layout. The distance between the furniture with each other is well considered, making it easier for tourists to explore the store. The store also sells many products from various brands and organizes these products by category.

The average auditory indicator is related to store design and aesthetics is 4.26 with $59.09 \%$ of the answers agreeing. Auditory in retail settings related to noise pollution such as customer chatter, sound of services or advertisements, and noise from employees needs to be addressed by presenting music to divert noise pollution in-store. Based on the results of the questionnaire, respondents agree that the atmosphere in the store is calm, away from noise pollution from other customers, service voices, or employees and listening to music in the midst of their shopping activities provides its own pleasure and comfort.

The average olfactory indicator is related to store design and aesthetics is 4.03 with $60 \%$ of the answers agreeing. Store's hygine is a must and always be considered by retailers because stores that are not paying any attantion to the hygine cause unpleasant odors that make customers uncomfortable. There are times when stores are crowded, causing customers to jostle with each other for some time and making the air quality in the store worse. The results of the questionnaire stated the store maintains air quality by placing fans in several corners.

The average tactile indicator is related to store design and aesthetics is 4.12 with $59.09 \%$ of the answers agreeing.. The touch intended in this study relates to how customers obtain information about the product and its characteristics ranging from weight, shape, structure to the packaging, and others.

Based on the results of the questionnaire, respondents agreed that they touched every type of product in the store to obtain information about the product they wanted to buy and they expressed more confidence in making a purchase after evaluating the product. This study also obtained information about autotelic personality which is the customer's desire to touch the product to meet the hedonic motivation in the form of pleasure. The results indicated that the respondents agreed that they also touched the products even though they did not intend to buy just for their pleasure. Respondents with this autotelic personality are likely to trigger impulse buying.

\section{Outer Model Evaluation}

The evaluation of outer model is used to test the validity and reliability of the research instrument. This study uses two forms of constructs, formative construct on the store atmosphere variable (X1) and reflective on the emotional variable (Y1), customer experience (Y2), and intention to visit again (Y3). The following are some of the validity and reliability tests of the questionnaires available on the WarpPLS.

The evaluation for the formative construct is indicators of reliability and collinearity. The reliability indicator can be seen from the significant weight value with the $\mathrm{p}$-value $\leq 0.05$. Collinearty is seen from the variance inflation factor (VIF), provided that the VIF $\leq 2.5$.

Table 1. Formative construct evaluation

\begin{tabular}{cccc}
\hline Indicator & $\mathrm{X} 1$ & VIF & P-Value \\
\hline $\mathrm{X} 1.1$ & 0.304 & 2.410 & $<0.001$ \\
$\mathrm{X} 1.2$ & 0.288 & 2.082 & $<0.001$ \\
$\mathrm{X} 1.3$ & 0.300 & 2.342 & $<0.001$ \\
$\mathrm{X} 1.4$ & 0.295 & 2.220 & $<0.001$ \\
\hline
\end{tabular}

Source: Primary data, processed (2021)

Reflective construct evaluation includes evaluation of validity and reliability. Evaluation of validity through convergent validity and 
discriminant validity, while reliability evaluation can be tested through composite reliability and cronbach's alpha.

Convergent validity can be evaluated by looking at the load factor value of each indicator. A research instrument meets the indicator reliability test if it has a loading factor value of more than 0.30 and significant.
Discriminant validity for the questionnaire or all indicators was evaluated by comparing the square root of the AVE for each construct with the correlation values between constructs in the model. If the value of the square root of AVE in each variable is greater than the correlation between variables in the model, then it has met the criteria.

Table 2. Combined loadings and cross loadings

\begin{tabular}{ccccccc}
\hline Indicator & X1 & Y1 & Y2 & Y3 & P-value & Conclution \\
\hline Y1.1 & 0.064 & $\mathbf{( 0 . 8 7 5 )}$ & -0.030 & 0.063 & $<0.001$ & Valid \\
Y1.2 & -0.045 & $\mathbf{( 0 . 8 8 3 )}$ & -0.115 & -0.087 & $<0.001$ & Valid \\
Y1.3 & -0.019 & $\mathbf{( 0 . 8 8 1 )}$ & 0.144 & 0.024 & $<0.001$ & Valid \\
Y2.1 & 0.004 & 0.162 & $\mathbf{( 0 . 9 2 7 )}$ & -0.104 & $<0.001$ & Valid \\
Y2.2 & -0.004 & -0.162 & $\mathbf{( 0 . 9 2 7 )}$ & 0.104 & $<0.001$ & Valid \\
Y3.1 & -0.063 & 0.044 & 0.074 & $\mathbf{( 0 . 9 2 3 )}$ & $<0.001$ & Valid \\
Y3.2 & 0.063 & $-0,044$ & -0.074 & $\mathbf{( 0 . 9 2 3 )}$ & $<0.001$ & Valid \\
\hline
\end{tabular}

Source: Primary data, processed (2021)

Table 3. Square root of the AVE

\begin{tabular}{cccccc}
\hline Variable & X1 & Y1 & Y2 & Y3 & Conclution \\
\hline X1 & $\mathbf{( 0 . 8 4 2 )}$ & 0.440 & 0.492 & 0.492 & Valid \\
Y1 & 0.440 & $\mathbf{( 0 . 8 8 0 )}$ & 0.705 & 0.683 & Valid \\
Y2 & 0.492 & 0.705 & $\mathbf{( 0 . 9 2 7 )}$ & 0.611 & Valid \\
Y3 & 0.492 & 0.683 & 0.611 & $\mathbf{( 0 . 9 2 3 )}$ & Valid \\
\hline
\end{tabular}

Source: Primary data, processed (2021)

Table 4. Cronbach's alpha and composite reliability

\begin{tabular}{cccc}
\hline Variable & Cronbach's alpha & Composite reliability & Conclution \\
\hline X1 & 0.863 & 0.907 & Reliable \\
Y1 & 0.854 & 0.911 & Reliable \\
Y2 & 0.837 & 0.925 & Reliable \\
Y3 & 0.827 & 0.920 & Reliable \\
\hline
\end{tabular}

Source: Primary data, processed (2021)

\section{Inner Model Evaluation}

Evaluation of the inner model shows the relationship between latent variables. The purpose of this evaluation is to determine the influence between variables in this research model. Evaluation can be seen through R-square (R2), Q-square (Q2), and full collinearity VIF.

Table 5. R-squared $\left(\mathrm{R}^{2}\right)$ and $\mathrm{Q}$-squared $\left(\mathrm{Q}^{2}\right)$

\begin{tabular}{ccc}
\hline Variable & R-Squared & Q-squared \\
\hline Y1 & 0.200 & 0,208 \\
Y2 & 0.556 & 0.561 \\
Y3 & 0.577 & 0.584
\end{tabular}

Source: Primary data, processed (2021)

Based on the output results above, the R-Squared value for the $\mathrm{Y} 1$ variable is 0.200 which means the contribution of the $\mathrm{X} 1$ variable to $\mathrm{Y} 1$ is $20 \%$ and the rest is influenced by other variables outside the model and errors. R-squared for variable Y2 has a value of 0.556 which means that the influence of variables $\mathrm{X} 1$, and $\mathrm{Y} 1$ on $\mathrm{Y} 2$ is $55.6 \%$ and the remaining $44.6 \%$ is influenced by other variables outside the model and errors. The R-squared value of the Y3 variable is 0.577 which means that the influence of the $\mathrm{X} 1, \mathrm{Y} 1$, and $\mathrm{Y} 2$ variables on $\mathrm{Y} 3$ is $57.7 \%$ and the remaining $42.3 \%$ is influenced by other variables outside the model and errors. The output estimation results above also show good predictive validity because the Q-squared values of the response variables in this study are $0.208,0.561$, and 0.584 , which are greater than zero.

Table 6. Full collinearity VIF

\begin{tabular}{c|c|c}
\hline Variable & Criteria & Full collinearity VIF \\
\hline X1 & & 1.430 \\
Y1 & $<3.3$ & 2.492 \\
Y2 & & 2.236 \\
Y3 & & 2.122 \\
\hline
\end{tabular}

Source: Primary data, processed (2021)

Evaluation of full collinearity VIF is a full collinearity test that includes vertical and lateral multicollinearity. Lateral collinearity is the collinearity between the explanatory latent variable 
and the criteria and can be used to test common method bias.

\section{Mediation Model Analysis}

The mediating variable is a variable acts as an intermediary for the relationship between explanatory variable and response variable. An important characteritic of the mediating variable is that this variable follows explanatory variable, then influences response variable

Table 7. Mediation model testing

\begin{tabular}{ccc}
\hline \multicolumn{1}{c}{ Path } & Coefficient & P-value \\
\hline $\mathrm{X} 1 \longrightarrow \mathrm{Y} 1 \longrightarrow \mathrm{Y} 3$ & 0.290 & $<0.001$ \\
\hline $\mathrm{X} 1 \longrightarrow \mathrm{Y} 1 \longrightarrow \mathrm{Y} 2$ & 0.266 & $<0.001$ \\
\hline $\mathrm{Y} 1 \longrightarrow \mathrm{Y} 2 \longrightarrow \mathrm{Y} 3$ & 0.112 & 0.045 \\
\hline $\mathrm{S} 1 \mathrm{Y}$
\end{tabular}

Source: Primary data, processed (2021)

The influence of the store atmosphere on the intention to revisit through emotion has a p-value of $<0.001$ so that it can be interpreted that emotion is a mediating variable. This means that the retailer is better at paying attention to the atmosphere of the store as well as possible so that it creates positive emotions for customers while interacting with the store atmosphere so that these positive emotions affect customer behavior in the future.

The effect of store atmosphere on customer experience through emotion has a p-value of $<0.001$. A well-designed store atmosphere will create positive customer emotions so that customers have a memorable experience in the store. So, it can be said that emotion is a mediating variable between store atmosphere and customer experience.

Table 8. Effect total testing
The influence of emotion on the intention to revisit through customer experience has a p-value of 0.045 , which means that customer experience is a mediating variable. The better the retailer creates customer emotions make customers have a memorable experience so that customers want to have the same experience in the future, and intend to visit again in the future.

\section{Effect Total Analysis}

This analysis was conducted to determine the overall effect of the store atmosphere variable, emotion variable, customer experience variable and revisit intention variable.

Table 8 provides information the strength of store atmosphere's influence (X1) on customer experience (Y2) is $27.5 \%$ greater than the strength of store atmosphere (X1) on revisit intention (Y3) is $22.4 \%$ and emotion (Y1) is $19.9 \%$.

The strength of emotion's influence (Y1) on customer experience (Y2) is $35.4 \%$. Then strength of emotion's influence (Y1) on the intention to revisit (Y3) of $44.7 \%$, while the strengthof customer experience's influence (Y2) on the intention of visiting again (Y3) of 3.5\% means that the strength of emotion's influence (Y1) is greater than customer experience ( $\mathrm{Y} 2$ ) in influencing the intention to revisit (Y3). Thus emotion (Y1) can be prioritized, considering that the absolute contribution is greater so that it shows the greatest strength of influence.

\begin{tabular}{|c|c|c|c|c|}
\hline \multirow{2}{*}{\multicolumn{2}{|c|}{ Endogen Variable }} & \multicolumn{3}{|c|}{ Effect Total } \\
\hline & & $\mathrm{X} 1$ & Y1 & $\mathrm{Y} 2$ \\
\hline \multirow[t]{2}{*}{ Y1 } & (1) & 0.447 & & \\
\hline & (2) & $<0.001$ & & \\
\hline \multirow[t]{2}{*}{ Y2 } & (1) & 0.259 & 0.595 & \\
\hline & (2) & 0.002 & $<0.001$ & \\
\hline \multirow[t]{2}{*}{ Y3 } & (1) & 0.133 & 0.540 & 0.189 \\
\hline & (2) & 0.075 & $<0.001$ & 0.020 \\
\hline \multicolumn{5}{|c|}{ Contribution } \\
\hline \multirow{3}{*}{\multicolumn{2}{|c|}{$\begin{array}{l}\mathrm{X} 1 \longrightarrow \mathrm{Y} 1=(0.447)^{2} \times 100 \%=19.9 \% \\
\mathrm{X} 1 \longrightarrow \mathrm{Y} 2=(0.525)^{2} \times 100 \%=27.5 \% \\
\mathrm{X} 1 \longrightarrow \mathrm{Y} 3=(0.474)^{2} \times 100 \%=22.4 \%\end{array}$}} & & \multirow{3}{*}{\multicolumn{2}{|c|}{$\begin{array}{l}\mathrm{Y} 1 \longrightarrow \mathrm{Y} 2=(0.595)^{2} \times 100 \%=35.4 \% \\
\mathrm{Y} 1 \longrightarrow \mathrm{Y} 3=(0.652)^{2} \times 100 \%=44.7 \% \\
\mathrm{Y} 2 \longrightarrow \mathrm{Y} 3=(0.189)^{2} \times 100 \%=3.5 \%\end{array}$}} \\
\hline & & & & \\
\hline & & & & \\
\hline
\end{tabular}

Note: (1) Path coefficient, (2) P-value

Source: Primary data, processed (2021)

Hypothesis Testing

.Table 9. Hypothesis testing

\begin{tabular}{ccc}
\hline $\mathrm{H} y$ pothesis & Coefficient & P-value \\
\hline $\mathrm{X} 1 \longrightarrow \mathrm{Y} 1$ & 0.447 & $<0.001$ \\
\hline $\mathrm{X} 1 \longrightarrow \mathrm{Y} 2$ & 0.259 & 0.002 \\
\hline $\mathrm{X} 1 \longrightarrow \mathrm{Y} 3$ & 0.133 & 0.075 \\
\hline $\mathrm{Y} 1 \longrightarrow \mathrm{Y} 2$ & 0.595 & $<0.001$ \\
\hline $\mathrm{Y} 1 \longrightarrow \mathrm{Y} 3$ & 0.540 & $<0.001$ \\
\hline
\end{tabular}

\begin{tabular}{ccc}
\hline $\mathrm{Y} 2 \longrightarrow \mathrm{Y} 3$ & 0.189 & 0.020 \\
\hline Source: Primary data, processed (2021) &
\end{tabular}

Hypothesis accepted if the p-value is 0.10 (alpha $10 \%$ ) and if the $p$-value is $>0.10$ then the hypothesis is rejected

This effect is shown by the path coefficient value of 0.447 with p-value $<0.001$. The results of the analysis prove that with the improvement of the storeping environment, the better the atmosphere of 
the store is able to stimulate positive emotions from tourists.

The results of this study extend previous research conducted by Gunawan and Tulpa (2014) that physical facilities are considered capable of creating satisfaction, product display and place of purchase are considered capable of evoking positive consumer emotions. Consumers with positive emotions, as a result of a pleasant environment, tend to feel satisfied and have the intention to buy the same product in the future. In line with the research above, according to research by Helmefalk (2017), if the retailer's goal is to offer a sensory experience to shoppers, then sensory cues need to be considered in designing the atmosphere of the store. And give information about the significant effect of visual, music, and aroma on positive emotions of customers.

Based on the results of the questionnaire, respondents claimed to be happy and satisfied when shopping at the store. They also stated that the storeping environment in the store was created according to respondents' perceptions so that they were more excited when they were in the store.

The results of the analysis provide information that the atmosphere of the store has a positive and significant influence on customer experience. This influence is shown from the path coefficient value of 0.259 with a p-value of 0.002 meaning that with the improvement of the storeping environment, it affects the customer experience in the form of a positive evaluation.

The results of this study strengthen the theory of Shahijan (2015) which states that experience plays an important role in the context of tourism because basically tourists seek experience on their journey. According to the results of the questionnaire, respondents stated that they had shopped at the store more than three times while traveling to Batu City. The average reason that makes most choose to shop at the same place is because the store has a large parking lot, a spacious building, the products are neatly arranged and according to category, also the service from friendly employees is the main reason for most of the respondents in this study.

The results of the analysis show that there is a positive and significant effect of the store atmosphere variable on the intention to return. The relationship between these variables gets a path coefficient value of 0.133 with a p-value of 0.075 , meaning that every improvement in the storeping environment increases the respondent's intention to return.

The output of the store atmosphere's influence on the revisit intention in this study extends the validity of research by Jalil (2016) which emphasizes that a good store atmosphere will lead to positive behavioral intentions such as revisit intentions and recommendations from customers. Based on interviews in the field, some respondents are often interested in the exterior of the store such as the building area and parking area before deciding to shop at the store.

The results of the analysis show that the emotion variable has a positive and significant effect on the customer experience variable. This effect is shown by the coefficient value of 0.595 and $p$-value $<0.001$ meaning the more positive the customer's emotions when interacting with the storeping environment, the better the experience created in the customer's mind.

The results of this study extend the validity of the research results of Ha and Soo (2019) which states that the customer experience arises through feelings of pleasure, the store creates stimulation to the five senses through interior decoration, music, delicious food and drinks, comfortable atmosphere and furniture. Considering that the respondents in this study are tourists, positive emotions are very important because tourists are basically looking for experiences on their journey.

The research output also expands the use of stimulus - organism - response theory in which the store atmosphere is in the form of a stimulus to create positive or negative emotions so that the emotions felt by customers when interacting with the storeping environment lead to an approach or rejection of customer behavior in form of evaluation.

The results of the analysis show that there is a positive and significant influence of the emotional variable on the variable of revisit intention. This effect is shown by the path coefficient value of and p-value $<0.001$ meaning that when the emotional response is more positive, the higher the customer's intention to visit again.

This study extends the applicability of the results of research conducted by Bilgihan (2016) which states that by considering the role of emotions in services being able to retain customers, companies need to pay attention to customer emotions and research conducted by Kandampully (2015) states that customer loyalty comes from positive emotional experiences, especially in service sector. Customer emotions help companies to create and retain loyal customers.

The results of the analysis state that the customer experience variable has a positive and significant effect on the variable of revisit intention. This influence is shown by the path coefficient value of 0.189 and $p$-value of 0.020 , meaning that the more positive the experience in the minds of customers, the more customers will want to visit the store again in the future.

The results of this study support Aziz's research (2010) showing that travel experiences to certain destinations increase the intention to revisit in the future and Kim's (2012) research which states that when individuals perceive tourism experiences as 
memories, they remember elements of the experience such as excitement, enjoyment, entertainment. , pleasure, meaning, and so on. This study also extends the theory of Jin et al. (2015) that previous experience is an important factor that can influence the intention to revisit because individuals who revisit have shown various attributes in their behavior.

\section{CONCLUSION}

Store atmosphere has a positive and significant effect on emotions, customer experience, and revisit intention. Emotions also have a positive and significant influence on customer experience and revisit intention. Customer experience has a positive and significant influence on revisit intention

Shopping tourism in Batu city has a store atmosphere according to their perception. The store has a strategic location, a spacious building equipped with a parking area and public facilities such as toilets, restaurants, prayer rooms.

On the inside, retailer arranges the layout between shelves and other furniture properly so that the allocation of space is effective, employees are also uniformed and environmentally friendly, lighting and colors in the store are also in accordance with the applied theme, product information, relevant discounts. Air circulation in the store is well maintained even though the store only uses fans in some places and the cleanliness in the store area is also quite maintained. The condition of the store is calm, accompanied by music that makes tourists comfortable shopping. Most of the respondents in the study have autotelic personalities so they collect a lot of information on the products offered.

The strategy's can be applied by retailers is to pay attention on cleanliness of public facilities areas such as toilets and prayer rooms. Maintaining the store's visuals, especially in the design section because it's not about apart from aesthetics it also functions to build the image of the store, arranging products according to categories so as not to hinder traffic patterns in the store, especially when there are many visitors.

\section{REFERENCES}

Adams, C., \& Doucé, L. (2017). What's in a scent? Meaning, shape, and sensorial concepts elicited by scents. Journal of Sensory Studies, 32(2). https://doi.org/10.1111/joss.12256

Ariani, N. M., \& Aryanti, N. N. (2018). Peran Kepuasan dan Niat Berperilaku Wisatawan Pasca Kunjungan pada Destinasi Pariwisata Bali. 2(2), 110-119.

Aziz, S., Bahadur, W., Zulfiqar, S., Sarwar, B., Chandia, K. E., \& Iqbal, M. B. (2018). Do emotions bring customers to an environment: Evidence from Pakistani shoppers? Cogent
Business and Management, 5(1), 1-23. https://doi.org/10.1080/23311975.2018.15363 05

Badan Pusat Statistik. (2020). Statistik Kunjungan Wisatawan Mancanegara Tahun 2019. Badan Pusat Statistik. https://jambikota.bps.go.id/

Badan Pusat Statistik Kota Batu. (2019). Kota Batu Dalam Angka (Batu Municipality in Figures) 2019. Badan Pusat Statistik Kota Batu, 250255.

Ballantine, P. W., Jack, R., \& Parsons, A. G. (2010). Atmospheric cues and their effect on the hedonic retail experience. International Journal of Retail and Distribution Management, 38(8), 641-653. https://doi.org/10.1108/09590551011057453

Banat, A., \& Wandebori, H. (2012). Store Design and Store Atmosphere Effect on Customer Sales per Visit. 84-89.

Buyin, H. R. (2018). IImpact of Store Environment on Impulse Buying (A case of International Modern Trade Retailers in Karachi). KASBIT Business Journals (KBJ), 11(1), 57-76.

Chen, S. C., \& Lin, C. P. (2015). The impact of customer experience and perceived value on sustainable social relationship in blogs: An empirical study. Technological Forecasting and Social Change, 96, 40-50. https://doi.org/10.1016/j.techfore.2014.11.01 1

de Wijk, R. A., Maaskant, A. M., Kremer, S., Holthuysen, N. T. E., \& Stijnen, D. A. J. M. (2018). Supermarket shopper movements versus sales and the effects of scent, light, and sound. Food Quality and Preference, 70, 3239.

https://doi.org/10.1016/j.foodqual.2017.03.01 0

Ha, J., \& Jang, S. C. (2012). The effects of dining atmospherics on behavioral intentions through quality perception. Journal of Services Marketing, 26(3), 204-215. https://doi.org/10.1108/08876041211224004

Hawkins, D. I., \& Mothersbaugh, D. L. (2010). Consumer Behaviour:Building Marketing Strategies. www.mhhe.com

Helmefalk, M. (2019). Browsing behaviour as a mediator: the impact of multi-sensory cues on purchasing. Journal of Consumer Marketing, 36(2), 253-263. https://doi.org/10.1108/JCM10-2017-2392

Helmefalk, M., \& Hultén, B. (2017). Multi-sensory congruent cues in designing retail store atmosphere: Effects on shoppers' emotions and purchase behavior. Journal of Retailing and Consumer Services, 38(March), 1-11. https://doi.org/10.1016/j.jretconser.2017.04.0 07 
Hussain, R., \& Ali, M. (2015). Effect of Store Atmosphere on Consumer Purchase Intention. International Journal of Marketing Studies, $7(2)$, https://doi.org/10.5539/ijms.v7n2p35

Hutmacher, F. (2019). Why Is There So Much More Research on Vision Than on Any Other Sensory Modality? Frontiers in Psychology, 10(October).

https://doi.org/10.3389/fpsyg.2019.02246

Jung, T., Ineson, E. M., Kim, M., \& Yap, M. H. T. (2015). Influence of festival attribute qualities on Slow Food tourists' experience, satisfaction level and revisit intention: The case of the Mold Food and Drink Festival. Journal of Vacation Marketing, 21(3), 277-288. https://doi.org/10.1177/1356766715571389

Kandampully, J., \& Tingting (christina) Zhang. (2016). Article information: Customer Loyalty: A Review and Future Directions With A Special Focus on The Hospitality Industry.

Kandampully, J., Zhang, T. (Christina), \& Bilgihan, A. (2015). Customer loyalty: A review and future directions with a special focus on the hospitality industry. International Journal of Contemporary Hospitality Management, 27(3), 379-414. https://doi.org/10.1108/IJCHM-03-2014-0151

Kim, J., \& Noh, J. (2018). Effects of Casino Servicescape and Customer Interaction on Chinese and Japanese Customers 'Emotions and Loyalty *.

Kusumawati, A., Utomo, H. S., Suharyono, S., \& Sunarti, S. (2020). Effects of sustainability on WoM intention and revisit intention, with environmental awareness as a moderator. Management of Environmental Quality: An International Journal, 31(1), 273-288. https://doi.org/10.1108/MEQ-03-2019-0064

Maguire, L., \& Geiger, S. (2015). Emotional timescapes: The temporal perspective and consumption emotions in services. Journal of Services Marketing, 29(3), 211-223. https://doi.org/10.1108/JSM-02-2014-0047

Möller, J., \& Herm, S. (2013). Shaping Retail Brand Personality Perceptions by Bodily Experiences. Journal of Retailing, 89(4), 438446.

https://doi.org/10.1016/j.jretai.2013.05.004

Mossberg, L. (2007). A Marketing Approach to the Tourist Experience. Scandinavian Journal of Hospitality and Tourism, 7(1), 59-74. https://doi.org/10.1080/15022250701231915

Nell, C., \& Wiid, J. (2013). Sight: The Last Bastion Of The Brick And Morter Retailer To Survive? International Business \& Economics Research Journal (IBER), 13(1), 125. https://doi.org/10.19030/iber.v13i1.8363
Nusairat, N. M. (2015). The Effect of Shopping Environment on Jordanian Mall Customers' Behaviour: The Mediating Role of Customers' Emotions and Cognition. University of Salford, September.

Pino, G., Amatulli, C., Nataraajan, R., De Angelis, M., Peluso, A. M., \& Guido, G. (2020). Product touch in the real and digital world: How do consumers react? Journal of Business Research, 112(June 2019), 492-501. https://doi.org/10.1016/j.jbusres.2019.10.002

Pradana, N. R., \& Wardana. (2019). Pengaruh Store Atmosphere Terhadap Keputusan ( Studi pada Keluarga Konsumen Toko Ritel di Yogyakarta ). Jurnal Ilmu Manajemen, 16(2), 71-82.

Roschk, H., Loureiro, S. M. C., \& Breitsohl, J. (2017). Calibrating 30 Years of Experimental Research: A Meta-Analysis of the Atmospheric Effects of Music, Scent, and Color. Journal of Retailing, 93(2), 228-240. https://doi.org/10.1016/j.jretai.2016.10.001

Shahijan, M. K., Rezaei, S., \& Amin, M. (2018). Qualities of effective cruise marketing strategy: Cruisers' experience, service convenience, values, satisfaction and revisit intention. International Journal of Quality and Reliability Management, 35(10), 2304-2327. https://doi.org/10.1108/IJQRM-07-2017-0135

Soh, K. L., Jayaraman, K., Choo, L. P., \& Kiumarsi, S. (2015). The impact of background music on the duration of consumer stay at stores: An empirical study in malaysia. International Journal of Business and Society, 16(2), 247260. https://doi.org/10.33736/ijbs.567.2015

Velasco, C., \& Spence, C. (2018). Multisensory packaging: Designing new product experiences. In Multisensory Packaging: Designing New Product Experiences. https://doi.org/10.1007/978-3-319-94977-2

Yan, M., \& Li, Q. (2016). Consumer behavior in coffee drinking: Comparison between Chinese and Swedish university students. 107.

Zhang, H., Wu, Y., \& Buhalis, D. (2018). A model of perceived image, memorable tourism experiences and revisit intention. Journal of Destination Marketing and Management, 8(June), 326-336. https://doi.org/10.1016/j.jdmm.2017.06.004 
Appendix 1. Indicator loading and Cross loading

\begin{tabular}{|c|c|c|c|c|c|c|c|}
\hline & $\mathrm{X} 1$ & $\mathrm{Y} 1$ & Y2 & Y3 & Type (as defined) & SE & P value \\
\hline $\mathrm{X} 1.1$ & $(0.863)$ & 0.179 & -0.117 & 0.064 & Formative & 0.076 & $<0.001$ \\
\hline $\mathrm{X} 1.2$ & $(0.817)$ & 0.045 & -0.153 & -0.068 & Formative & 0.077 & $<0.001$ \\
\hline $\mathrm{X} 1.3$ & $(0.852)$ & -0.136 & 0.066 & 0.028 & Formative & 0.076 & $<0.001$ \\
\hline $\mathrm{X} 1.4$ & $(0.837)$ & -0.090 & 0.203 & -0.028 & Formative & 0.077 & $<0.001$ \\
\hline Y1.1 & 0.064 & $(0.875)$ & -0.030 & 0.063 & Reflective & 0.076 & $<0.001$ \\
\hline $\mathrm{Y} 1.2$ & -0.045 & $(0.883)$ & -0.115 & -0.087 & Reflective & 0.076 & $<0.001$ \\
\hline Y1.3 & -0.019 & $(0.881)$ & 0.144 & 0.024 & Reflective & 0.076 & $<0.001$ \\
\hline Y2.1 & 0.004 & 0.162 & $(0.927)$ & -0.104 & Reflective & 0.075 & $<0.001$ \\
\hline Y 2.2 & -0.004 & -0.162 & $(0.927)$ & 0.104 & Reflective & 0.075 & $<0.001$ \\
\hline Y3.1 & -0.063 & 0.044 & 0.074 & $(0.923)$ & Reflective & 0.075 & $<0.001$ \\
\hline Y3.2 & 0.063 & -0.044 & -0.074 & $(0.923)$ & Reflective & 0.075 & $<0.001$ \\
\hline
\end{tabular}

Appendix 2. Latent Variable Coefficient

\begin{tabular}{|c|c|c|c|c|c|}
\hline & $\mathrm{X} 1$ & Y1 & Y2 & Y3 & \\
\hline R-squared & & 0.200 & 0.556 & 0.577 & \\
\hline Adj. R-squared & & 0.192 & 0.548 & 0.565 & \\
\hline Composite reliab. & 0.907 & 0.911 & 0.925 & 0.920 & \\
\hline Cronbach's alpha & 0.863 & 0.854 & 0.837 & 0.827 & \\
\hline Avg. var. extrac. & 0.709 & 0.774 & 0.860 & 0.852 & \\
\hline Full collin. VIF & 1.430 & 2.492 & 2.236 & 2.122 & \\
\hline Q-squared & & 0.208 & 0.561 & 0.584 & \\
\hline Min & -2.994 & -3.856 & -2.441 & -2.681 & \\
\hline Max & 1.573 & 1.883 & 1.540 & 1.773 & \\
\hline Median & -0.230 & -0.027 & 0.213 & 0.288 & \\
\hline Mode & -0.230 & 0.448 & 0.213 & 0.288 & \\
\hline Skewness & -0.231 & -0.514 & -0.406 & -0.230 & \\
\hline Exc. kurtosis & -0.005 & 1.862 & -0.103 & 0.368 & \\
\hline Unimodal-RS & Yes & Yes & Yes & Yes & \\
\hline Unimodal-KMV & Yes & Yes & Yes & Yes & \\
\hline Normal-JB & Yes & No & Yes & Yes & \\
\hline Normal-RJB & Yes & No & No & No & \\
\hline Histogram & View & View & View & View & \\
\hline
\end{tabular}

Appendix 3. Model fit and Quality indices

\section{Model fit and quality indices}

Average path coefficient $(A P C)=0.360, P<0.001$

Average R-squared (ARS) $=0.444, P<0.001$

Average adjusted R-squared (AARS) $=0.435, P<0.001$

Average block VIF (AVIF) $=1.552$, acceptable if $<=5$, ideally $<=3.3$

Average full collinearity VIF (AFVIF) $=2.070$, acceptable if $<=5$, ideally $<=3.3$

Tenenhaus GoF (GoF) $=0.596$, small $>=0.1$, medium $>=0.25$, large $>=0.36$

Sympson's paradox ratio $(S P R)=1.000$, acceptable if $>=0.7$, ideally $=1$

$R$-squared contribution ratio $(R S C R)=1.000$, acceptable if $>=0.9$, ideally $=1$

Statistical suppression ratio $(S S R)=1.000$, acceptable if $>=0.7$

Nonlinear bivariate causality direction ratio $(\mathrm{NLBCDR})=1.000$, acceptable if $>=0.7$ 


\section{Appendix 4. Structural Model}

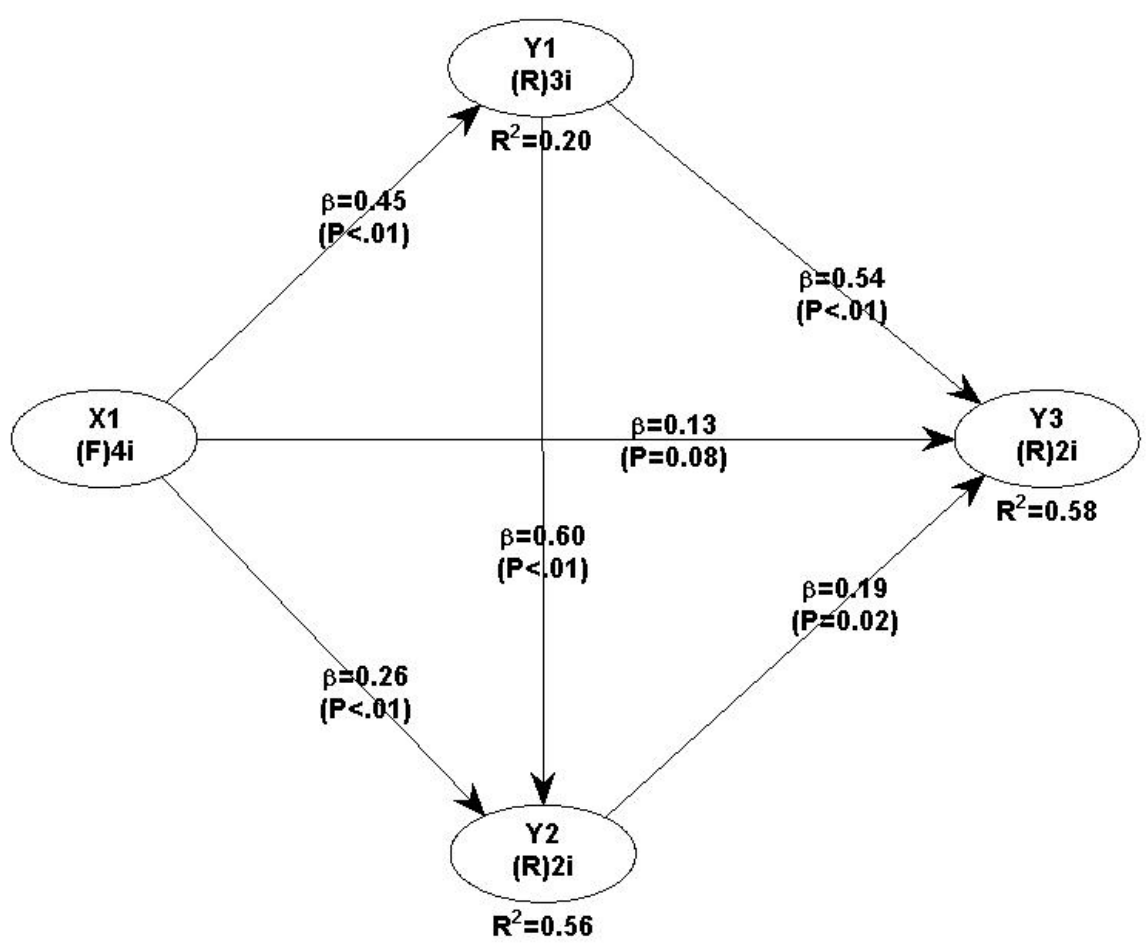

